\title{
Bisnis Halal dalam Perspektif Etika Islam: Kajian Teoritis
}

\author{
An Ras Try Astuti ${ }^{1 *}$, Rukiah $^{2}$ \\ ${ }^{1,2}$ Institut Agama Islam Negeri (IAIN) Parepare \\ *email:anrastryastuti@iainpare.ac.id
}

\begin{abstract}
Abstrak
Islam sebagai ajaran Rahmatan lil alamin memberikan pedoman kepada kehidupan umat, agar tercipta keseimbangan di alam semesta. Untuk itu Sang Pencipta melalui Nabi Muhammad SAW, memberikan petunjuk jalan kebenaran kepada setiap manusia. Tidak terkecuali, Petunjuk yang terkait bagaimana mengkonsumsi produk yang baik bagi fisik maupun spiritual. Makanan yang baik adalah makanan yang masuk kategori dihalalkan dalam ajaran agama. Halal tidaknya suatu makanan merupakan hal yang paling penting untuk masyarakat muslim. Di era pasar bebas saat ini, peluang pasar untuk produk halal sangat besar, sehingga Negara-Negara muslim melalui lembaga syariahnya harus dituntut untuk menangani masalah sertifikasi halal dari suatu produk. Karena produk yang sudah bersertifikat halal akan lebih mudah untuk memasuki pasar internasional yang makin akomodatif dengan nilai-nilai yang diyakini umat Islam.
\end{abstract}

Kata kunci : Islam, etika dan halal

\begin{abstract}
Islam is the teaching of Rahmatan lil alamin which has given guidance to the life of the people, in order to create a balance in the universe. For this reason, the Creator through the Prophet Muhammad SAW, gave instructions for the truth to every human being. No exception, the instructions related to how to consume products that are both physical and spiritual. Good food is food that is categorized as practiced in religious teachings. Halal or not food is the most important thing for Muslim communities. In the current era of free markets, the market opportunity for halal products is very large, so Muslim countries through their sharia institutions must be required to deal with the problem of halal certification of a product. Because products that are halal certified will be easier to enter the international market which is increasingly accommodating to the values believed by Muslims.
\end{abstract}

Keywords: Islam, ethics and halal

\section{Pendahuluan}

Manusia merupakan khalifah Tuhan di muka bumi menjadi dasar filosofis etika, sehingga apabila manusia berperilaku sesuai amanah khalifah maka dihitung sebagai ibadah. Akibat dari konsep khalifah adalah manusia akan betangggung jawab di 
akhirat pada setiap perilaku dalam hidupnya. Ajaran islam yang mencakup aspekaspek kehidupan Ajaran islam disebut dengan syariah. Istilah Syariah berasal dari kata bahasa Arab yang memiliki arti sebagai jalan yang harus diikuti. Secara harfiah ia berarti "jalan ke sebuah mata air". Ia bukan hanya jalan menuju keridhaan Allah yang Maha Agung, melainkan juga jalan yang diimani oleh seluruh kaum Muslimin sebagai jalan yang dibentangkan oleh Allah, Sang Pencipta itu sendiri, melalui utusan-Nya, Nabi Muhammad SAW( Abdurrahman: 1991, 1). Selain itu, syariah adalah seperangkat norma, aturan, nilai yang membentuk cara hidup islam. Norma-norma syariah dapat digunakan sebagai dasar pembentukan etika bisnis islam.

Sementara manusia dituntut untuk pertanggung jawab terhadap setiap aspek hidupnya, timbul masalah yang berkait denngan waktu dan tempat. Olehnya itu syariah kemudian tidak stagnan akan tetapi dinamis, hal ini bertujuan untuk menjawab setiap tantangan dan problem dari tiap zaman yang berbeda. Metode yang digunakan adalah metode fiqh, yaitu metode penalaran, intrepretasi dan penilaian terhadap syariat. Hal ini karena fiqih merupakan piranti pokok yang mengatur secara mendetail perilaku kehidupan umat selama dua puluh empat jam setiap harinya (Goldziher: 1987, 1). Metodologi ini kemudian bisa dipakai untuk menjawab isu-isu etika kontemporer.

Tantangan utama yang dihadapi oleh sistem etika adalah praktek. Banyak artikel yang diterbitkan membahas tentang etika bisnis islam secara normative. Akan tetapi banyaknya artikel tersebut tidak sebanding dengan praktek etika di Negara muslim sendiri. Padahal ketimpangan antara etika normative dan etika yang berlaku di masyarakat disebabkan karena tidak efektifnya lembaga-lembaga keagamaan dalam menerjemahkan konsep etika normative kedalam kehidupan nyata.

Meskipun etika islam kadang dianggap sebagai etika idealis, akan tetapi pada dasarnya tidak ada perbedaan antara konsep etika islam dengan konsep etika agama lain. Fakta bahwa peradaban islam pernah menjadi peradaban maju di dunia selama berabad-berabad adalah bukti bahwa konsep islam khususnya etika bisa diturunkan ke dalam bentuk praktis. Fleksibilitas dan kemampuan beradaptasi etika islam juga merupkan bagian dari syariat islam. Hal ini dikuatkan juga oleh hadist Nabi yang mengatakan bahwa ada tiga tingkatan iman yaitu: Islam, Iman dan Ihsan.

Fredric Canney mengusulkan bahwa setiap konsep etika harus memiliki aspek kewajiban, kebajikan dan komponen nilai. Ketiga kriteria tersebut juga sejalan dengan tiga level syariah, yaitu islam yang sejajar dengan aspek kewajiban, Iman yang sejajar dengan aspek Kabajikan dan ihsan yang sejajar dengan aspek Komponen Nilai. Konsep etika islam juga sejalan dengan konsep etika normative tradisional yang juga memiliki tiga tingkatan, etika deontologi, etika konsekuensionalis dan etika moralis.

Untuk itu artikel ini bertujuan untuk mengeksplorasi peluang menggunakan aturan dan sertifikat halal sebagai upaya untuk mewujudkan praktek etika bisnis islam di dunia kontemporer. Diskusi tentang etika saat ini kebanyakan bersifat normatif, untuk itu perlu kiranya diarahkan untuk menemukan akar yang kuat dari etika praktis. Konsep dasar etika islam tidak berubah, karena bersumber dari Al quran.

\section{Pembahasan}

\section{Regulasi dan Sertifikasi Halal}

Halal atau tidaknya suatu makanan merupakan hal yang paling penting untuk masyarakat muslim, dalam era bisnis saat ini yang dimulai dengan masuknya makanan dari Negara Non Muslim ke Negara muslim di Tahun 1970 an menuntut untuk segera 
diterapkannya lembaga yang bertugas secara khsusus untuk menangani masalah sertifikasi halal dari suatu produk. Negara-negara seperi Malaysia, Singapura dan Indonesia saat ini telah membentuk lembaga-lembaga yang khusus yang mengawasi halal atau tidaknya makanan yang masuk dari Negara Non Muslim. Saat ini sertifikasi halal terdapat di Industri Makanan/Obat dan keuangan, akan tetapi sertifikasi halal juga akan dikembangkan ke Industri lain, seperti Kosmetik, pariwisata dll.

Sebelum dikeluarkannya UU No 33 tahun 2014 tentang Jaminan Produk Halal (UU JPH), Majelis Ulama Indonesia (MUI) telah menerbitkan sertifikat halal berdasarkan kesepakatan Menteri Agama, Menteri Kesehatan dan Ketua MUI. Sejak tahun 1989 hingga sekarang, MUI telah mengeluarkan sertifikat halal tanpa memaksakan produsen untuk mendapatkan sertifikat halal, karena sifatnya yang sukarela (voluntary).

Dengan adanya sertifikasi halal yang dilakukan oleh MUI maka sertifikat halal itu merupakan fatwa tertulis terhadap status kehalalan suatu produk. Pada pasal 4 UU JPH dinyatakan bahwa "Produk yang masuk, beredar dan diperdagangkan di wilayah Indonesia wajib bersertifikat halal". Produk yang wajib adalah barang dan/atau jasa yang terkait dengan makanan, minuman, obat, kosmetik, produk kimiawi, produk biologi, produk rekayasa genetik, serta barang gunaan yang dipakai, digunakan, atau dimanfaatkan oleh masyarakat. Sehingga dengan adanya jaminan produk halal maka pelaku usaha dapat meningkatkan nilai tambah untuk memproduksi dan menjual produk halalnya. Selain itu, Jaminan Produk Halal juga meningkatkan daya saing produk di global market, sehingga dapat memberikan kontribusi bagi peningkatan dan pertumbuhan ekonomi Negara .

Tahun 2015, potensi sertifikat halal di Indonesia 1.614.149 Industri mikro kecil (BPS, 2015) dan 1.619.897 industri makanan dan minuman (BPS, 2015). Dari potensi yang besar tersebut, sampai tahun 2017 LPPOM MUI baru mensertifikasi 440.238 produk dari 40.946 perusahaan. Oleh karenanya, terbuka peluang sebagai Lembaga Pemeriksa Halal sesuai kewajiban sertifikasi halal pada Oktober 2019 nanti khususnya bagi Usaha Mikro Kecil dan Menengah (UMKM).

Sistem hukum yang ada Indonesia dapat menjadi acuan karena merupakan sebuah sistem aturan yang berlaku di negara Indonesia memiliki aturan yang sangat luas, Kedudukan Sertifikasi Halal Dalam Sistem Hukum Nasional merupakan salah satu upaya dalam Perlindungan dari unsur-unsur hukum, dimana di antara unsur hukum yang satu dengan yang lain saling berhubungan, saling mempengaruhi satu sama lainnya. Oleh karenanya membahas atau membicarakan satu bidang atau unsur atau subsistem hukum yang berlaku di Indonesia tidak bisa dipisahkan dari yang lain, seperti halnya tubuh manusia yang terdiri dari rangkaian organ-organ, maka sistem hukum juga bagaikan satu organ yang keberadaannya tidak bisa dipisahkan dari organ yang lain.

Upaya memahamkan masyarakat tentang kehalalan lagi ketoyyiban sangat diperlukan. Oleh karena itu, informasi tersebut harus diinformasikan secara efektif dan operasional kepada masyarakat. Kegiatan ini dapat efektif ketika didukung dengan sarana dan prasarana yang memadai. Salah satu sarana penting untuk mengawal doktrin halal dimaksud adalah hadirnya pranata hukum yang mapan, sentral, humanis, progresif, akomodatif, dan tidak diskriminatif, yakni Undang Undang Jaminan Produk Halal.

Undang-undang Nomor 33 Tahun 2014 tentang Jaminan Produk Halal (atau disiingkat UUJPH) disahkan oleh Dewan Perwakilan Rakyat tepat pada tanggal 25 
September 2014. Hadirnya Undang-Undang tersebut diharapkan dapat memberikan kontribusi dan jawaban bagi masyarakat dan dunia usaha dalam rangka perlindungan terhadap konsumen dan sekaligus menjadi payung hukum berbagai macam jenis produk halal pada produk makanan, minuman, obat, kosmetik, produk kimia, produk biologi, dan produk rekayasa genetika.

Dengan diberlakukannya UU Jaminan Produk Halal ini diharapkan produkproduk Indonesia dapat bersaing/berkompetisi dengan produk-produk asing/luar negeri tentunya hal ini juga harus dibarengi dengan peningakatan mutu dan kualitas . sehingga dapat diminati oleh konsumen terutama konsumen yang beragama Islam baik konsumen lokal maupun asing.

Undang-Undang Jaminan Produk Halal seidealnya mampu mengintegrasikan konsep- konsep kehalalan produk untuk dapat dikonsumsi atau digunakan konsumen muslim menurut aturan hukum Islam, menjadi hukum materiil dan hukum formal dalam undang-undang sebagai sub sistem hukum nasional.

Secara komprehensip/menyeluruh aspek kehalalan mencakup bahan baku yang digunakan dalam mengolah produk, proses produk dan pemasaran produk. Bahan baku dan produk menurut undang-undang ini mengadopsi pendekatan yang lebih luas, yaitu mencakup makanan, minuman, obat, kosmetika, produk kimia biologis dan rekayasa genetika.

Produk produksi produk halal wajib tunduk pada ketentuan keseluruhan rangkaian produksi mulai dari alat, bahan, ruang produksi, penyimpanan, distribusi, dan penyajian yang halal sesuai hukum Islam.

Proses produksi halal juga mencakup proses produksi halal dengan bahan baku hewani, bahan baku nabati, dan proses kimia biologis atau rekayasa genetika. Ada tiga kekuatan berlakunya UUJPH, yaitu: pertama, kekuatan berlaku yuridis (juristische geltung). Berkaitan dengan sertifikasi halal ini, maka filosofis pranata hukum yang mendasarinya adalah: a) Dominan agama adalah al-Qurean dan al-Hadits; b) sedangkan pada dominan hukum positif didasarkan pada Undang-Undang Nomor 36 Tahun 2009 tentang Kesehatan, Undang-Undang Nomor 18 Tahun 2012 tentang Pangan , Undang-Undang Nomor 8 Tahun 1999 tentang Perlindungan Konsumen dan terakhir Undang-Undang Nomor 33 Tahun 2014 tentang Jaminan Produk Halal. Oleh karena itu, dapat disimpulkan bahwa kedudukan sertifikasi halal dalam sistem hukum Nasional di Indonesia mempunyai kedudukan yang sentral, karena sertifikasi halal telah termaktub dalam Undang-Undang Nomor 33 Tahun 2014 tentang Jaminan Produk Halal yang secara sistem hukum merupakan bagian dari sistem hukum, yaitu substansi hukum yang mempunyai kekuatan hukum dan kepastian hukum serata bersifat imperative (Panji: 2017,161). Dan hal ini merupakan upaya dalam perlindungan konsumen yang sesuai dengan hukum islam.

\section{Harmonisasi Standar dan Struktur Tata Kelola}

Pada tanggal 31 Oktober tahun 2018 telah dilaksanakan World Halal Food Council (WHFC) dalam rangka Annual General Meeting, kegiatan ini dihadiri 36 lembaga yang berasal dari berbagai delegasi, industri, pemerintahan, organisasi penelitian, universitas, dan asosiasi konsumen. Pertemuan ini ditujukan untuk mengevaluasi program selama satu tahun dan membahas berbagai masalah kontemporer terkait produk halal global.

Tentu ini sangat dinantikan pelaku bisnis. Standar internasional itu diharapkan mengefisienkan dan meningkatkan akurasi proses sertifikasi halal. Besarnya peluang 
bisnis produk halal dunia menyita perhatian pelaku bisnis. Setidaknya ada tiga tema terkait produk halal yang dihasilkan selama 2018, fatwa terkait penggunaan alkohol dalam produk pangan, obat, dan kosmetika, fatwa terkait plasma darah, dan fatwa terkait dengan konsumsi Kanguru.

WHFC adalah wadah berhimpun lembaga sertifikasi halal dunia yang keanggotaannya berasal dari seluruh negara di dunia. Hingga kini, anggota WHFC berjumlah 65 delegasi dari 22 negara. WHFC dibentuk untuk mengarusutamakan kehalalan produk yang dikonsumsi umat Islam sebagai wujud perlindungan pada konsumen.

Pertemuan di Jakarta merupakan pertemuan tahunan yang diikuti oleh seluruh lembaga sertifikasi halal anggota WHFC seluruh dunia guna membahas berbagai permasalahan kontemporer di bidang kesyariahan serta perkembangan teknologi pangan. Pertemuan juga membahas strategi konsolidasi agar isu halal terus menjadi isu utama dalam produk pangan. Di samping anggota WHFC, pertemuan diikuti pula oleh lima lembaga sebagai observer. Bersamaan dengan acara pertemuan tahunan WHFC digelar acara Indonesia Halal Expo (INDHEX). Halal Expo menjadi acara tahunan di berbagai negara. Thailand, Australia, dan Selandia Baru dikenal sebagai penghasil produk bersertifikat halal termasuk Indonesia. Menteri Koordinator Bidang Perekonomian Darmin Nasution mengatakan pasar konsumsi mamin penduduk Muslim pada 2016 lalu diestimasikan sebesar US\$169,7 miliar. "Pengeluaran konsumsi nilai transaksi makanan halal global pada 2016 mencapai US \$1,2 triliun atau 17 persen dari pengeluaran konsumsi makanan secara global.

Besarnya potensi transaksi penduduk muslim di Indonesia karena mayoritas masyarakat dalam negeri masih menjadi target konsumen, baik dari barang impor maupun produk lokal. Selain itu, industri halal lainnya yang menjadi incaran masyarakat Indonesia, yakni industri farmasi.

Jumlah konsumsinya pada 2016 lalu tercatat US\$5,7 miliar. Kemudian, tingkat konsumsi kosmetik halal juga cukup tinggi sebesar US\$3,7 miliar. Sementara itu, tingkat belanja busana halal di Indonesia pada 2016 lebih tinggi dari farmasi, yakni US\$13,5 miliar. Bila dibandingkan dengan tingkat konsumsi busanan halal secara global, angka itu berada dalam peringkat kelima. Dari sisi produksinya, Indonesia tidak termasuk dalam lima besar negara pengekspor busana musim terbesar dunia.

Beberapa industri tersebut merupakan sebagian contoh perkembangan di sektor riil. Sementara itu, Darmin memaparkan total aset keuangan syariah di Indonesia juga menanjak setiap tahunnya. Total aset keuangan syariah Indonesia pada 2016 sebesar US\$47,6 miliar dan pada tahun lalu naik menjadi US\$81,8 miliar. Peningkatan itu membuat peringkat aset keuangan syariah Indonesia secara global menjadi ketujuh dari sebelumnya berada di peringkat sembilan. Data Otoritas Jasa Keuangan (OJK) pada 31 Maret 2018 total aset keuangan syariah Indonesia US\$82,3 miliar, pangsa pasar tersebut 8,4 persen terhadap keuangan secara nasional.Secara terpisah,

Menteri Perencanaan Pembangunan Nasional (PPN/Bappenas) Bambang Brodjonegoro berharap Indonesia tak hanya menjadi konsumen semata. Sebab, jika produksi industri halal Indonesia bisa diekspor maka akan mengurangi defisit neraca transaksi berjalan. Melihat kondisi tersebut maka pemerintah harus bergerak cepat untuk melihat peluang terhadap tingginya permintaan akan produk halal.

Pada kuartal I 2018 neraca transaksi berjalan defisit sebesar US\$5,5 miliar. Kondisi itu dipicu oleh defisit neraca pendapatan primer yang defisit sebesar US\$7,9 miliar dan defisit pendapatan jasa sebesar US\$1,4 miliar (CNN Indonesia:2018). 
Pesatnya bisnis produk halal belum didukung secara kuat pengembangan Sistem Jaminan Halal (Halal Assurance System) dan kelembagaan sertifikasi halal global dan diratifikasi banyak negara. Saat ini, lembaga yang ada banyak bersifat nasional, belum terstandarisasi, dan belum ada lembaga auditornya.

Di Indonesia, sertifikasi halal ditangani Lembaga Pengkajian Pangan, Obatobatan, dan Kosmetika Majelis Ulama Indonesia (LPPOM-MUI). Di luar negeri banyak lembaga sertifikasi halal dalam satu negara. Riaz dan Caudry (2004) mencatat dari 40 lembaga sertifikasi halal di AS tahun 2001, hanya 16 lembaga yang diakui Jabatan Kemajuan Islam Malaysia (Jakim), bahkan hanya lima yang diakui MUI. Ini bukan tanpa alasan. Lembaga sertifikasi halal luar negeri ada yang ditangani hanya 2-3 orang dan diragukan kredibilitasnya. Oleh karena itu, dinilai tepat langkah LPPOM MUI mengeluarkan 39 lembaga sertifikasi halal luar negeri yang direkomendasi di antaranya di Australia 11, Selandia Baru 3, AS 8, Belanda 3, Irlandia 4. Sementara itu, di Singapura, Malaysia, Thailand, Philipina, dan Jepang masing-masing 1 lembaga direkomendasi.

Kondisi itu akan menggerus kepercayaan konsumen dan mempersulit produsen dan pebisnis produk halal antarnegara. Sertifikat halal dari lembaga sertifikasi halal suatu negara, sering ditolak majelis ulama dan atau lembaga sertifikasi halal negara lain. Lembaga sertifikasi halal yang dipercaya negara pengimpor harus melakukan sertifikasi ulang. Hal ini menyebabkan inefisiensi bagi semua pihak. Perbedaan hasil audit produk dari AS pernah terjadi. Dimana produk dianggap halal tetapi LPPOM MUI menilai belum memenuhi standar halal. Jika terus berlangsung, hak konsumen memperoleh jaminan produk halal akan terabaikan.

Dalam Upaya penyatuan standar halal telah dilakukan. Pada 2003, MUI mengintroduksi standardisasi lembaga fatwa halal bagi ASEAN. Februari 2004 anggota World Halal Council (WHC), yang sekarang dipimpin ketua LPOM MUI, menyepakati persyaratan lembaga sertifikasi halal dan prosedur umum sertifikasi halal. Demikian juga prosedur standar untuk audit flavor, produk mikrobial, dan penyembelihan hewan. Pada konferensi WHC 2007 di Malaysia telah dicapai standardisasi sertifikasi halal bagi anggotanya. Selain itu juga, kerja sama Indonesia, Malaysia, Thailand Growth Triangle (IMT- GT). Pada 2008, WHF ke-3 memberi mandat International Halal Integrity Alliance (IHI Alliance) untuk mengembangkan standar halal internasional. Hasilnya di presentasikan pada WHF ke-4 Mei 2009. Menghasilkan standar halal internasional bukan perkara mudah, melainkan tidak mustahil. Beberapa problem di antaranya.

Pertama, perbedaan mazhab dan ushul fikih ulama komisi fatwa juga memengaruhi halal tidaknya suatu produk. Misalnya, sebagian ulama menilai semua makanan laut halal, sedang ulama lain menilai kepiting, cumi dan belut tidak termasuk makanan halal.

Kedua, dalam upaya memastikan kehalalan, auditor harus memeriksa langsung ke semua tempat produksi atau cukup menerima info tertulis jika dianggap tidak terkait dengan bahan yang berpotensi haram.

Ketiga, pendekatan standar audit yang digunakan. Dalam standar Internasional Organization For Standardization (ISO) ada toleransi seperti standar kualitas. Namun, kehalalan dalam Islam tidak ada toleransi (zero tolerant). Begitu satu bahan atau proses diragukan kehalalannya, harus diganti atau diperbaiki agar memperoleh sertifikat halal. Ke depan, harmonisasi dan standardisasi sertifikasi halal antarlembaga dan atau antarnegara perlu dilakukan bertahap. Kita berharap sertifikasi halal internasional akan 
diterima berbagai pihak. Hal ini menguntungkan.Pertama, memperjelas model audit lembaga sertifikasi halal. Kedua, efisiensi proses produksi bagi produsen dan pelaku bisnis karena tidak perlu sertifikasi ulang yang menambah biaya. Ketiga, lebih menjamin terpenuhinya hak konsumen. Selayaknya standar yang dipakai berdasarkan ajaran Islam, karena halal adalah Islamic term dan Islamic law. Dibutuhkan kerja sama lebih erat antarlembaga sertifikasi halal, produsen, ulama, peneliti, dan pemerintah, serta pihak-pihak terkait.

Kita berharap berkembangnya standar halal internasional akan mendorong tumbuhnya bisnis produk halal. Dengan ditopang proses sertifikasi halal yang efisien dan akurat akan memudahkan pelaku bisnis dan menguntungkan semua pihak.

Kendala utama yang dihadapi oleh Negara-negara muslim terhadap sertifikasi halal produk-produk yang masuk dari luar adalah tidak adanya standarisasi halal yang jelas dari setiap Negara. Dan tidak ada mekanisme kerja sama sertifikasi halal antar Negara. Namun, dalam indutri keuangan, standar halal lebih mudah dibanding dengan industri lainnya. Hal ini disebabkan karena adanya lembaga keuangan internasioanl yang didirikan untuk mengatur tata kelola sistem keuangan Islam.

Untuk bekerja secara efektif perlu adanya mekanisme standar halal internasional antar Negara muslim, hal ini juga untuk memudahkan jalannya perdagangan Internasional. Untuk itu perlu didirikan lembaga internasional di industri lain, seperti makanan dan kosmetik. Praktek etika bisa dijadikan standar sertifikasi halal. Selain itu dengan memanfaatkan jaringan Corporate social Responsibility (CSR) yang dimiliki oleh perusahaan bisa menjadi modal kuat untuk mendirikan etika bisnis islam Modern. Untuk menemukan dasar filosofis dari konsep etika islam dan menemukan mekanisme yang tepat untuk menentukan standar dari regulasi dan sertifikasi halal sebagai bagian dalam mewujudkan etika islam dalam perdagangan internasional kontemporer.

\section{Tanggung Jawab Bisnis Halal dalam Konsep Etika Islam}

Pada dasarnya konsep etika islam tidaklah stagnan, akan tetapi cenderung dinamis dan kontesktual. Selain itu etika islam yang bersumber dari ajaran syariah juga memiliki dasar hokum dari Al Quran dan Sunnah. Selain itu, dasar filosofis dari etika islam, yakni konsepsi manusia sebagai khalifah dibumi. Dengan konsepsi ini meniscayakan setiap manusia akan bertanggung jawab terhadap setiap perbuatannya, dan karennya akan mendorong manusia untuk berprilkau secara etis dalam setiap kehidupannya. Namun, dasar filosofis tersebut tidak cukup untuk menjelaskan kenapa manusia harus berprilaku etis, denga hanya mengatakan bahwa manusia bertanggung jawab terhadap perbuatannya. Sebagaimana yang diketahui bahwa kata islam berasal dari akar kata salamah yang berarti selamat. Itu berarti selain islam memiliki konsepsi tentang khalifah, islam juga punya doktrin teolologis (teo $=$ tujuan, logos $=$ diskursus). Menurut islam bahwa tujuan hidup manusia bukan hanya di bumi tapi juga di akhirat.

Dalam salah satu ayat al quran dijelaskan bahwa manusia diciptakan dengan dasar fitrah, yaitu kecenderungan kearah kesempurnaan(Mutahhari: 1994,1). Jadi tujuan hidup manusia sudah ditetapkan sejak kelahiranny, yaitu menuju kesempurnaan. Namun berbeda dengan konsep plato yang hanya melihat kesempurnaan hanya ada di alam idea. Dalam konsep islam, ide kesempurnaan merupakan proses yang harus dijalani dalam hidupnya.

Disebut harus, karena ide kesempurnaan memang merupakan tujuan dasar manusia, hanya dalam kehidupan praktis manusia salah mengkonsepsi dengan melihat kesempurnaan ada pada penempukan kekayaan dan kekuasaan, sehingga berbabgai 
cara digunakan untuk mencapai tujuan tersbut, meskipun harus mengorbankan orang lain.

Dalam Tesis Mulla Sadra, beliau menjelaskan bahwa setiap saat manusia senantiasa bergerak, baik pada tataran aksiden maupun substansial. Gerak itu seperti yang dijelaskan oleh Aristoteles bertujuan menuju kepada penggerak itu sendiri. Yang dalam konsep teologis disebut Tuhan. Kembali ke Mulla Sadra, menurutnya gerak manusia bersifat evolusioner mulai dari jiwa tambang, jiwa tumbuhan, jiwa hewan sampai kepada jiwa manusia.

Jiwa manusia adalah kualitas yang dicapai hanya jika dalam hidupnya senantiasa hidup berperilaku etis/berakhlak. Manusia yang hidupnya hanya terbatas pada pemenuhan kepauasan makan minum dan sex oleh Mulla Sadra disebut hanya memiliki jiwa hewan. Penjelasan Mulla Sadra ini sejalan dengan hadist yang menagatakan bahwa diakhirat nanti ketika manusia dibangkitkan, kondisi manusia akan bermacam-macam bentuk, ada yang menyurupai monyet, babi, anjing, ular dan lain-lain. Model manusia ketika dibangkitkan tergantung kepada jiwa apa yang actual dalam dirinya ketika manusia tersebut hidup di dunia. Manusia yang hidupnya penuh kelicikan dan tipu daya, maka diakhirat nanti akan dibangkitkan menyerupai ular berbisa, begitupun manusia yang hidupnya hanya untuk kesenagan (hedonis) maka dia akan dibangkitkan dengan menyerupai babi.

Dari tesis Mulla Sadra tersebut, kita menarik kesimpulan bahwa keharusan ber etika tidak hanya karena manusia merupakan Khalifah Tuhan di Bumi, tapi juh lebih dalam dari itu. Etika/akhlak merupakan jalan menuju kesempurnaan manusia. Untuk itu etika merupakan kemestian yang harus dipraktekkan oleh setiap manusia.

Disinilah letak pentingnya lembaga syariah islam Seperti Majelis Ulama Indonesia (MUI). Lembaga ini seharusnya tidak hanya sebatas menerbitkan aturanaturan dan sertifikasi Halal. Tapi lembaga ini mesti turun tangan mengedukasi msyarakat akan pentinganya penerapan etika dalam kehidupan sehari-hari.

Kemungkinan penerapan etika berdasarkan regulasi dan sertifikasi halal, Etika juga tidak hanya berdasarkan aturan-aturan tapi lebih kepada internalisiasi. Karena jika hanya sebatas aturan, manusia tidak merasakan pentinganya etika tersebut dalam kehidupan praktisnya.

Dalam kajian Psikologi, seperti yang dijelakan oleh Jalaludin Rahmat dalam bukunya Psikologi Komunikasi. Ada tiga Model kepatuhan. Yaitu kepatuhan karena adanya aturan, sepeti patuhnya bawahan terhadap bosnya, kedua kepatuhan karena adanya kesadaran bahwa ada manfaat ketika dia patuh. Seperti patuhnya seorang pasien kepada dokter yang menyarankan untuk minum obat meskipun dia tidak suka. Akan tetapi pasien tersebut sadar bahawa obat tersebut bermanfaat untuk kesahatannya. Yang ketika kepatuhan yang bersifat internalisasi, yaitu kepatuhan Karen adanya kesempurnaan di dalamnya. Seperti patuhnya seorang fans terhadap idolanya, sehingga fans tersebut tidak hanya ingin meniru idolanya tapi juga ingin menjadi idolanya.

Model kepatuhan yang ketigalah diharapkan, bahwa manusia tidak hanya meihat etika sebagai kepatuhan karena adanya manfaat tapi memang melihat etika tersebut sebagai kesempurnaan hidupnya.

Terakhir, kemungkinan mendorong kerja sama Corporate Social Responsibility (CSR) setiap perusahaan dengan lembaga sertifikasi dan regulasi Halal untuk mendorong terwujudnya model bisnis yang berlandaskan etika islam. Ini adalah usulan yang cukup inovatif. Untuk itu perlu kiranya ada penelitian lebih lanjut mengenai 
kemungkinan adanya integrasi kedua pihak tersebut.

\section{Kesimpulan}

Keinginan manusia dalam memnuhi kebutuhan akan konsumsi halal membuat pemasok dan produsen menyesuaikan produk yang ditawarkan dengan standar halal dalam Islam. Sertifikasi halal sebagai sistem jaminan kualitas yang menyeluruh dapat digunakan untuk memenangkan persaingan pasar dengan memenuhi kebutuhan konsumen yang terjamin kehalalannya. Masih sedikitnya pasokan produk yang terjamin tingkat kehalalannya menjadikan peluang pasar halal yang masih sangat terbuka lebar yang dapat dimanfaatkan oleh industri kecil maupun industri besar. Dengan kata lain, produk yang sudah bersertifikat halal akan lebih mudah untuk memasuki pasar internasional yang makin akomodatif dengan nilai-nilai yang diyakini umat Islam. Jika selama ini halal di Indonesia selalu ditanggapi dengan sentimen hegemoni agama, maka melalui tulisan ini diharapkan dapat memberikan wawasan baru kepada seluruh pemanfaat jasa dan barang yang selama ini berbeda pemahaman mengenai kebijakan halal. Dan akhirnya memberikan kesadaran kepada mereka bahwa Sertifikasi halal tidak akan merugikan agama lain, bahkan dapat memberikan jaminan agar produk mereka dapat diterima dengan mudah oleh konsumen muslim di seluruh dunia.

\section{Referensi}

Al Khanif. 2010. Hukum dan Kebebasan beragama di Indonesia, Yogyakarta: Laksbang Mediatama

BPJPH (Badan Penyelengara Jaminan Produk Halal), Kepala BPJPH Sosialisasikan UU JPH pada Pelaku Usaha. www.kemenag.go.id

Goldziher,(1987) "Fikh" dalam E.J. Brils First Encyclopaedia of Islam, Brill, Leiden, , Vol.3. https://www.cnnindonesia.com/ekonomi diakses pada tanggal 2 april 2019

Kartanegara, Mulyadhi (2002). Panorama Filsafat Islam. Bandung: Mizan.

Kazhim, Muza. (2001). "Kontroversi Seputar Akal, Hati, dan Eksistensi”. AlHuda, Vol.II.No.IV.

Mohsen Miri, Seyyed (2004). Sang Manusia Sempurna : Antara Filsafat Islam dan Hindu.

Jakarta: Teraju.

Muhsin Labib. (2005). Para Filosuf: sebelum dan sesudah Mulla Shadra. Jakarta: AlHuda. Mustamin al-Mandary (2003). Menuju Kesempurnaan: Persepsi Dalam Pemikiran Mulla

Shadra. Makassar: Safinah. 196 | REFLEKSI, Volume 15, Nomor 2, Oktober 2016

Muthahharî, Murthada Manusia Sempurna, terj. M. Mashem, (Jakarta: Lentera, cet. II,1994, Muthahhari, Murthada. (2002). Filsafat Hikmah: Pengantar Pemikiran Shadra. Terjemahan.

Tim Penerjemah Mizan. Bandung: Mizan.

Panji, Adam" Kedudukan Sertifikasi Halal Dalam Sistem Hukum Nasional Sebagai Upaya Perlindungan Konsumen Dalam Hukum Islam” Amwaluna, Vol. 1 No. 1 (Januari, 2017)

Rahman, Abdur I.Doi Inilah Syariah Islam, Pustaka Panji Mas, Jakarta. (1991)

Shadrâ, Mullâ (1999). Al-Hikmah al-Muta"liyyah fi al-Asfâr al-,Aqliyyah al"Arba"ah. Beirut: Dâr Ihyâ wa al-Turâts al-,,Arabi. 
Taqî, Muhammad Misbâh Yazdî (2003). Buku Daras Filsafat Islam. Terjemahan Musa Kazhim \& Saleh Bagir. Bandung: Mizan.

Ubaidillah, Ahmad, et.all, 2000, Pendidikan Kewargaan, Demokrasi, Ham dan Masyarakat Madani, Jakarta: IAIN Jakarta Press.

Wahid, Marzuki, Fiqh Indonesia, Kompilasi Hukum Islam dan Counter Legal Draft Kompilasi Hukum Islam Dalam Bingkai Politik Hukum Indonesia, cet. 1, Bandung : Marja.(2014)

Yahya, Mukhtar dan Fatchurrahman, 1997, Dasar-dasar Pembinaan Hukum Fiqh Islam, Bandung: Al-Maeearif 